\title{
The Pursuit of Precision in Paraneoplastic Neurologic Disease
}

Justin R. Abbatemarco, MD, and Stacey L. Clardy, MD PhD

Neurol Neuroimmunol Neuroinflamm 2021;8:e1015. doi:10.1212/NXI.0000000000001015

In this issue of Neurology ${ }^{\circledR}$ Neuroimmunology \& Neuroinflammation, Graus et al. have provided an update to the 2004 paraneoplastic neurologic syndromes (PNS) diagnostic criteria. ${ }^{1,2}$ Cancer and its remote effects in the body are not a new diagnostic entity. As early as the mid-1800s, Trousseau ${ }^{3}$ described recurrent thrombophlebitis in association with gastric carcinoma. Nonetheless, over the past few decades, there has been increasing awareness of paraneoplastic syndromes, especially those affecting the nervous system, underscoring the need for clear guidelines to ensure that diagnostic nomenclature is used correctly in both the clinical and research settings.

The authors specifically and appropriately acknowledged confusion around commonly used terminology and decided to move away from using the term "onconeural antibodies"-elimination of this term helps clarify that not all neural autoantibodies are associated with malignancy. The panel instead created 3 new risk categories to stratify autoantibodies and their associated syndromes (high-risk, intermediate-risk, and low-risk phenotypes) which offer more precise terminology when describing these conditions. In addition, these guidelines reinforce that a positive autoantibody result is not a "stand-alone" diagnosis, but rather a piece of supportive data that must always be interpreted in the correct clinical circumstance. The hope is that these guidelines provide improved clinical context for clinicians and specify appropriate malignancy evaluation.

The panel developed a new clinical scoring system called the PNS-Care Score. This calculator provides a level of diagnostic certainty in complicated clinical scenarios. Specifically, the PNS-Care Score encompasses the clinical syndromes in the presence of specific neuronal antibodies and/or cancer. The authors note that the criteria, by design, are rather specific and may underestimate the occurrence of PNS cases. Particularly, the authors wanted to avoid "incidental" antibody associations with commonly encountered malignancies, such as prostate cancer. This article also outlines updated cancer screening recommendations. Previous recommendations suggested screening for malignancy up to 4 years after the diagnosis of PNS. ${ }^{4}$ In this iteration, the authors recommend screening every 4-6 months for 2 years in patients with high-risk phenotypes/antibodies, with the caveat that the guidelines must be adapted to the individual case. For example, if a woman of reproductive age presents with a relapse of anti-N-methyl-D-aspartate receptor (NMDAR) encephalitis, further screening measures to identify a potential ovarian teratoma are appropriate regardless of the timeframe from the index diagnosis. Clinicians should also be aware of testing limitations (e.g., the limited sensitivity of CT imaging for breast malignancy). The specific screening modality should always be informed by the antibody/phenotype tumor association. Finally, the importance of ensuring all patients follow age-appropriate cancer screening measures-in addition to any specific monitoring dictated by the PNS phenotype-cannot be overemphasized in this population.

We commend the authors for taking a broad, comprehensive approach to these updated criteria. Specifically, the comments on the laboratory technique are an important message for all clinicians who order and interpret these assays. The interpretation of any autoantibody result must be combined with a comprehensive clinical evaluation. Caution should be used when interpreting an autoantibody that has low specificity for PNS, particularly when at low titers. ${ }^{5,6}$ Furthermore, the recent proliferation of assays of limited or unclear clinical significance can be

\author{
Correspondence \\ Dr. Clardy \\ stacey.clardy@hsc.utah.edu
}

RELATED ARTICLE

Updated Diagnostic

Criteria for Paraneoplastic

Neurological Syndromes

Page e1014 
confusing to distressed patients in search of a diagnosis, given their limited sensitivity/specificity or appropriate validation. In general, the most clinically relevant results are derived from immunohistochemistry/immunofluorescence with confirmatory assays (i.e., immunoblot and cell-based assay). ${ }^{5}$ Often clinicians and patients alike desire a single, simple test to diagnose medical conditions, making it all the more urgent to emphasize the danger of such an overly simplistic approach in the diagnosis of autoimmune and paraneoplastic neurologic conditions. It is unrealistic to expect that the results of neural autoantibody testing in isolation can provide a comprehensive understanding of this category of multisystem, immunologically complex diseases. Accurate diagnosis will always require a thoughtful synthesis of all available clinical features, with attention to the temporal and systemic context of symptoms, along with objective ancillary evidence, including autoantibodies, CSF abnormalities, and imaging abnormalities.

In this updated guideline, the authors address the effect on the field of malignancy-directed immune-checkpoint inhibitor immunotherapy. The beneficial effect of these therapies in oncological care has been remarkable, but these agents also have the potential to cause neurologic side effects, including the induction of PNS. ${ }^{7}$ The current PNS guidelines provide a diagnostic construct to approaching this subset of PNS. The interplay of these immunotherapies with PNS can be particularly challenging because many of the cancers that the immune-checkpoint inhibitors target overlap with cancer types frequently involved in traditional PNS, such as small-cell lung carcinomas. The authors have provided a framework for strategic management and future research, including emphasizing the value of screening for neuronal antibodies before initiating cancer immunotherapy. Most importantly, they emphasize maintaining vigilance in patients treated with immune-checkpoint inhibitor therapy because prompt recognition and treatment is imperative to achieve the best possible outcomes.

Recognition of PNS has expanded dramatically over the past few decades. Familiarity with these syndromes will facilitate prompt recognition and treatment, and these updated diagnostic criteria serve to expedite the diagnostic process. In particular, using unambiguous terminology along with evidence-based risk stratification is imperative. Clinicians must anchor a PNS diagnosis on objective clinical and laboratory evidence to ensure optimal outcomes for patients while also avoiding unnecessary treatments or interventions. The scope of immune-mediated disorders continues to evolve, especially regarding cancer immunotherapy-induced neurologic autoimmunity and PNS. There have been few studies investigating the diagnostic performance of the 2004 PNS criteria, and this lack of investigation limits the ability to interpret this latest iteration. ${ }^{8,9}$ Future studies need to examine how these guidelines perform in clinical practice, but our hope is that these updated recommendations will be easier to deploy and subsequently study.

\section{Study Funding}

No targeted funding reported.

\section{Disclosure}

J.R. Abbatemarco reports no disclosures relevant to the manuscript. S.L. Clardy: Editor, Neurology ${ }^{\circledR}$ Podcast and Neurology Minute; Research and/or Clinical Fellowship support from the Western Institute for Veterans Research, the SRNA, the IDF, Alexion, and Barbara Gural Steinmetz Foundation; and Consulting/Ad Board: Alexion, Genentech, VielaBio, Guidepoint, ExpertConnect, Clarion Healthcare Consulting (fees paid to University of Utah Development account). Go to Neurology.org/NN for full disclosures.

\section{Publication History}

Received by Neurology: Neuroimmunology \& Neuroinflammation March 19, 2021. Accepted in final form April 14, 2021.

\begin{tabular}{lll} 
Appendix & Authors \\
\hline Name & Location & Contribution \\
\hline $\begin{array}{l}\text { Justin R. } \\
\text { Abbatemarco, } \\
\text { MD }\end{array}$ & $\begin{array}{l}\text { University of Utah, Salt Lake } \\
\text { City }\end{array}$ & $\begin{array}{l}\text { Drafting/revision of the } \\
\text { article for content, } \\
\text { including medical writing } \\
\text { for content }\end{array}$ \\
\hline $\begin{array}{l}\text { Stacey L. } \\
\text { Clardy, MD, } \\
\text { PhD }\end{array}$ & $\begin{array}{l}\text { University of Utah \& George } \\
\text { Eedical Center, Salt Lake }\end{array}$ & $\begin{array}{l}\text { Drafting/revision of the } \\
\text { article for content, } \\
\text { including medical writing } \\
\text { for content }\end{array}$ \\
\hline
\end{tabular}

\section{References}

1. Graus F, Vogrig A, Muñiz-Castrillo S, et al. Updated diagnostic criteria for paraneoplastic neurological syndromes. Neurol Neuroimmunol Neuroinflamm 2021:8(4);e1014.

2. Graus F, Delattre JY, Antoine JC, et al. Recommended diagnostic criteria for paraneoplastic neurological syndromes. J Neurol Neurosurg Psychiatry. 2004;75(8): 1135-1140.

3. Trousseau A. Phlegmasia alba dolens. In: Lectures on clinical medicine, delivered at the Hotel-Dieu, Paris. London: London New Sydenham Society; 1865;5:281-332.

4. Titulaer MJ, Soffietti R, Dalmau J, et al. Screening for tumours in paraneoplastic syndromes: report of an EFNS task force. Eur J Neurol. 2011;18(1):19.e13.

5. Lang K, Pruss H. Frequencies of neuronal autoantibodies in healthy controls: estimation of disease specificity. Neurol Neuroimmunol Neuroinflamm. 2017; 4(5):e386.

6. Li Y, Jammoul A, Mente $\mathrm{K}$, et al. Clinical experience of seropositive ganglionic acetylcholine receptor antibody in a tertiary neurology referral center. Muscle Nerve. 2015;52(3):386-391.

7. Graus F, Dalmau J. Paraneoplastic neurological syndromes in the era of immunecheckpoint inhibitors. Nat Rev Clin Oncol. 2019;16(9):535-548.

8. Vogrig A, Gigli GL, Segatti S, et al. Epidemiology of paraneoplastic neurological syndromes: a population-based study. J Neurol. 2020;267(1):26-35.

9. Hebert J, Riche B, Vogrig A, et al. Epidemiology of paraneoplastic neurologic syndromes and autoimmune encephalitides in France. Neurol Neuroimmunol Neuroinflamm. 2020;7(6):e883. 


\section{Neurology \\ Neuroimmunology \& Neuroinflammation}

The Pursuit of Precision in Paraneoplastic Neurologic Disease

Justin R. Abbatemarco and Stacey L. Clardy

Neurol Neuroimmunol Neuroinflamm 2021;8;

DOI 10.1212/NXI.0000000000001015

This information is current as of May 13, 2021

\section{Updated Information \& Services}

References

Subspecialty Collections

Permissions \& Licensing

Reprints including high resolution figures, can be found at:

http://nn.neurology.org/content/8/4/e1015.full.html

This article cites 9 articles, 4 of which you can access for free at: http://nn.neurology.org/content/8/4/e1015.full.html\#\#ref-list-1

This article, along with others on similar topics, appears in the following collection(s):

All Immunology

http://nn.neurology.org//cgi/collection/all_immunology

Autoimmune diseases

http://nn.neurology.org//cgi/collection/autoimmune_diseases

Paraneoplastic syndrome

http://nn.neurology.org//cgi/collection/paraneoplastic_syndrome

Information about reproducing this article in parts (figures,tables) or in its entirety can be found online at:

http://nn.neurology.org/misc/about.xhtml\#permissions

Information about ordering reprints can be found online:

http://nn.neurology.org/misc/addir.xhtml\#reprintsus

Neurol Neuroimmunol Neuroinflamm is an official journal of the American Academy of Neurology.

Published since April 2014, it is an open-access, online-only, continuous publication journal. Copyright

Copyright $\odot 2021$ The Author(s). Published by Wolters Kluwer Health, Inc. on behalf of the American

Academy of Neurology.. All rights reserved. Online ISSN: 2332-7812.

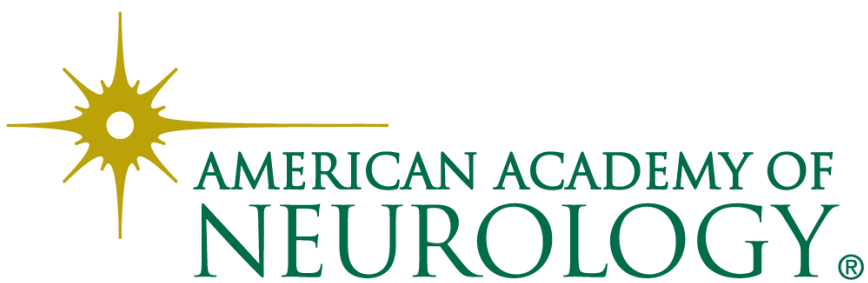

